\title{
Effects of $\beta$ receptor antagonists in patients with clinical evidence of heart failure after myocardial infarction: double blind comparison of metoprolol and xamoterol
}

\author{
Hans Persson, Eva Rythe'n-Alder, Anders Melcher, Leif Erhardt
}

\begin{abstract}
Objective-To evaluate whether xamoterol, a partial agonist, would improve exercise time more than metoprolol in patients with mild to moderate heart failure after a myocardial infarction.

Design-Single-centre double blind randomised parallel group comparison of metoprolol 50-100 $\mathrm{mg}$ and xamoterol 100-200 mg twice daily.

Patients-210 patients aged 40-80 years (173 men) with clinical evidence of heart failure early after a myocardial infarction. 106 were given metoprolol and 104 xamoterol.

Main outcome measures-Exercise test results and performance at three months; the exercise test, quality of life, and clinical assessments at baseline (5-7 days after the infarction) and after 3, 6, and 12 months.
\end{abstract}

Results-Exercise time increased at three months by $22 \%$ in the metoprolol group and $29 \%$ in the xamoterol group, but with no significant difference between the groups. Patients taking xamoterol showed overall non-significantly higher mean values of exercise time achieved with higher heart rates at rest and exercise. Improvements in quality of life, clinical signs of heart failure, and New York Heart Association functional class were seen in both treatment groups over one year, with minor benefits of xamoterol on breathlessness, peripheral oedema, and functional class. Eighteen patients taking metoprolol and 22 taking xamoterol withdrew from the study during one year, with a low mortality, reinfarction rate, and progress of heart failure in both treatment groups. Mean dose from baseline to 3 months was 135 mg metoprolol and $347 \mathrm{mg}$ xamoterol.

Conclusion- $\beta_{1}$ Receptor antagonists with or without partial agonist activity are safe to use in mild to moderate heart failure after a myocardial infarction. Exercise tolerance, quality of life, and clinical signs and functional class of heart failure improve, and few patients show deterioration in their condition. Exercise tolerance is no better with xamoterol than metoprolol.

(Br Heart f 1995;74:140-148)

Keywords: heart failure; myocardial infarction; metoprolol; xamoterol
Heart failure after a myocardial infarction is a common and serious complication, ${ }^{1}$ contributing appreciably to future morbidity and mortality ${ }^{2}$ irrespective of whether it is evaluated by clinical methods or objective measures of left ventricular function. ${ }^{3}$ Digitalis and diuretics have long been the mainstay of treatment in heart failure. Large scale studies have shown that angiotensin converting enzyme inhibitors improve prognosis and symptoms and exercise tolerance in patients with chronic heart failure ${ }^{45}$ with better effects on exercise tolerance than is obtained with digitalis. ${ }^{4}$ These inhibitors reduce mortality and morbidity in patients after myocardial infarction in those with asymptomatic left ventricular dysfunction $^{6}$ and those with clinical signs of heart failure. ${ }^{7} \beta$ Receptor antagonists substantially reduce mortality and morbidity after myocardial infarction especially in high risk patients with enlarged hearts or with clinical heart failure. ${ }^{89}$ The effect seems in addition to that of angiotensin converting enzyme inhibitors.

It has long been proposed that $\beta$ receptor antagonists can be functionally beneficial in patients with heart failure if used with caution. ${ }^{10}$ Prospective, randomised trials specifically of $\beta$ antagonists in patients with heart failure after infarction are lacking. Vasodilating properties or partial agonist activity have been suggested to reduce some of the negative inotropic or chronotropic effects of $\beta$ receptor antagonists, although concerns have been raised that the agonist activity could abolish the beneficial effect on mortality especially after myocardial infarction. ${ }^{11}$ Xamoterol, a $\beta_{1}$ receptor antagonist with high partial agonist activity improves symptoms and exercise tolerance in patients with mild to moderate chronic heart failure ${ }^{12}$ without deleterious effects on prognosis, ${ }^{13}$ although doubts have been raised in severe heart failure. ${ }^{14}$ The effect of xamoterol on exercise tolerance was superior to that of digitalis. ${ }^{12}$ Metoprolol, a $\beta_{1}$ receptor antagonist devoid of agonist activity, has been widely used after myocardial infarction and also improves exercise tolerance in patients with dilated cardiomyopathy. ${ }^{10} 15$

This prospective study was undertaken to compare the effects of these two types of antagonists on exercise tolerance, clinical assessment, and quality of life during one year in patients with mild to moderate heart failure soon after myocardial infarction. At the time of planning the study in 1987 it was hypothesised that xamoterol would improve exercise 
tolerance more than metoprolol because of its partial agonist activity. It was considered unethical to include a placebo group because of the routine use of $\beta$ receptor antagonists as secondary prevention at our institution in patients with stabilised heart failure. This is, to our knowledge, the first prospective randomised trial to assess the functional effects of $\beta$ receptor antagonists in heart failure after myocardial infarction.

\section{Patients and methods}

DESIGN

The study was a double blind randomised parallel group single centre comparison of metoprolol (50-100 mg twice daily) and xamoterol (100-200 mg twice daily) over a year. One cardiologist (HP) screened, randomised, and followed up all patients throughout the study. Patients were randomly allocated metoprolol or xamoterol at discharge 5-7 days after the index infarction. Stratification was based on enlargement of the left ventricle at the time of randomisation, with left ventricular end diastolic diameter of $\geqslant 28 \mathrm{~mm} / \mathrm{m}^{2}$ body surface area being considered to reflect an enlarged left ventricle. ${ }^{16}$ The primary efficacy variable in the study was exercise tolerance at three months. Secondary end points were exercise tolerance at six and 12 months, clinical assessment of heart failure, and quality of life during follow up.

Results of a previous study with xamoterol indicated that a total of 200 patients with completed exercise tests would be needed to give a $90 \%$ chance of detecting a $25(10 \%)$ seconds difference between the two groups at three months at the $5 \%$ level of significance. ${ }^{12}$ The protocol was approved by the ethics committee at Karolinska Hospital, and all patients gave their informed consent to take part. The study was conducted in accordance with the Declaration of Helsinki.

\section{PATIENTS}

Patients aged $40-80$ with one or more specified clinical or radiological signs of left ventricular heart failure (table 1) at any time during the 5-7 days in the coronary care unit after an acute myocardial infarction were included after their condition had stabilised. Patients with severe heart failure (New York Heart Association class IV) were excluded, as were patients with pulmonary disease, aortic stenosis, hypertrophic obstructive cardiomy-

Table 1 Occurrence of signs of heart failure in the two treatment groups. Values are numbers of patients

\begin{tabular}{lll}
\hline & $\begin{array}{l}\text { Metoprolol } \\
(n=106)\end{array}$ & $\begin{array}{l}\text { Xamoterol } \\
(n=104)\end{array}$ \\
\hline Bilateral pulmonary rales & 97 & 97 \\
Third heart sound & 51 & 58 \\
Congestion on $x$ ray film & 41 & 43 \\
Type of congestion: & 36 & 40 \\
$\quad$ Upper lobe diversion & 19 & 15 \\
$\quad$ Interstitial oedema & 1 & 2 \\
$\quad$ Alveolar oedema & 9 & 8 \\
$\quad$ Pleural effusion & 51 & 47 \\
Sinus tachycardia & 17 & 18 \\
Respiratory rate $>$ 27/minute & 17 & \\
\hline
\end{tabular}

opathy, unstable angina, drug misuse, other disabling diseases, or inability to carry out a two minute exercise test. Concurrent treatment was kept as stable as possible throughout the study, but diuretics (mainly frusemide), nitrates, angiotensin converting enzyme inhibitors, and digitalis were allowed. Angiotensin converting enzyme inhibitors were given only to patients whose heart failure deteriorated and who showed no response after adjustment of diuretics. Calcium antagonists were not allowed at baseline.

\section{METHODS}

All patients had a clinical assessment, chest radiography, echocardiography, and a symptom limited exercise test before randomisation and discharge. A questionnaire about symptoms and activities in their daily lives was filled in by the cardiologist. Randomised treatment was then started. Metoprolol $50 \mathrm{mg}$ or xamoterol $100 \mathrm{mg}$ was given twice daily on the first day. Heart rate and blood pressure were checked while patients were supine and standing before and two hours after each dose. On the second day the dose was doubled if no adverse reactions occurred. If adverse symptoms or signs of intolerance developed the patient was discharged taking a reduced trial dose. The lowest given dose before withdrawal was $50 \mathrm{mg}$ metoprolol or $100 \mathrm{mg}$ xamoterol once daily. A visit to check safety of treatment was made after four weeks of randomised treatment. Full assessments with an exercise test, quality of life questionnaire, and clinical assessment were made after three, six, and 12 months.

Effort tolerance was assessed by a symptom limited exercise test on a bicycle ergometer (Siemens Elema, Solna, Sweden) starting at $30 \mathrm{~W}$, with a continuous increase of $10 \mathrm{~W}$ each minute. Heart rate was measured every minute and blood pressure and respiratory rate every third minute and at peak exercise. ST depression $60 \mathrm{~ms}$ after the J point was measured at the end of exercise as the mean value from 3-5 consecutive beats in the lead $\left(\mathrm{V}_{4}-\mathrm{V}_{6}\right)$ showing the maximal ST deviation.

A capillary blood sample for estimation of blood lactate concentration was taken three minutes after exercise. The samples were analysed with the enzymatic method based on oxidation of L-lactate to pyruvate with a Lactate Analyzer 640 (Roche Bioelectrics, Basel, Switzerland). The patients' perception of chest pain, dyspnoea, and leg fatigue was assessed every minute and at peak exercise by using Borg scales $(0-10) .{ }^{17}$

Symptoms during daily life were assessed by Likert questionnaires, which included questions about breathlessness, tiredness, chest pain, palpitations, speed of walking and daily tasks, difficulty with walking and daily tasks, confidence, sleeping, and mood. The physician rated the answers given by the patient on a scale of four or five points.

A clinical assessment was performed noting presence of rales, a third heart sound, respiratory rate at rest, peripheral oedema, jugular venous filling, hepatojugular reflex, and 
hepatomegaly. The patients were assigned a New York Heart Association functional class at each visit.

Echocardiography was performed 3-5 days after the index infarction with $M$ mode recording of left ventricular end diastolic diameter from a short axis parasternal view below the level of the mitral valve ${ }^{16}$; left ventricular end diastolic diameter was related to body surface area. An Interspec XT, equipped with a $2.5 \mathrm{MHz}$ transducer, was used. Wall motion score according to Berning et $a l^{18}$ was determined at baseline in all patients with an acceptable cross sectional echo window.

Chest radiography was usually performed

Table 2 Characteristics of patients at baseline. Values are numbers of patients unless stated otherwise

\begin{tabular}{|c|c|c|}
\hline & $\begin{array}{c}\text { Metoprolol } \\
(n=106)\end{array}$ & $\begin{array}{c}\text { Xamoterol } \\
(n=104)\end{array}$ \\
\hline Men:women & $82: 24$ & $91: 13$ \\
\hline Median age (range) (years) & $66(46-80)$ & $67(40-80)$ \\
\hline Mean (SD) weight $(\mathrm{kg})$ & $77 \cdot 5(12 \cdot 0)$ & $76 \cdot 5(11 \cdot 1)$ \\
\hline \multicolumn{3}{|l|}{ New York Heart Association class: } \\
\hline I & 2 & 4 \\
\hline II & $7 \overline{8}$ & 65 \\
\hline III & 26 & 35 \\
\hline \multicolumn{3}{|l|}{ Medical history: } \\
\hline Myocardial infarction & 15 & 20 \\
\hline Left ventricular heart failure & 14 & 16 \\
\hline Hypertension & 33 & 28 \\
\hline Angina pectoris & 31 & 40 \\
\hline Diabetes mellitus & 17 & 19 \\
\hline \multicolumn{3}{|l|}{ Index infarction: } \\
\hline Transmural & 91 & 80 \\
\hline Anterior/lateral & 54 & 56 \\
\hline \multicolumn{3}{|l|}{ Peak infarct size (mean (SD) $\mu \mathrm{kat} / \mathrm{l})$} \\
\hline Aspartate aminotransferase & $5.00(3.57)$ & $4 \cdot 74(3 \cdot 17)$ \\
\hline Creatine phosphokinase & $37.5(33 \cdot 7)$ & $36.5(33.9)$ \\
\hline Creatine kinase B & $1.57(1.51)$ & $1.57(1.33)$ \\
\hline Lactate dehydrogenase & $22 \cdot 2(13 \cdot 5)$ & $26 \cdot 3(16 \cdot 5)$ \\
\hline \multicolumn{3}{|l|}{ At hospital: } \\
\hline Ventricular fibrillation & 5 & 9 \\
\hline Ventricular tachycardia & 47 & 44 \\
\hline \multicolumn{3}{|l|}{ Atrioventricular block } \\
\hline I & 5 & 3 \\
\hline II & 1 & 2 \\
\hline III & 3 & 4 \\
\hline \multicolumn{3}{|l|}{ Treatment before admission to hospital: } \\
\hline Diuretics & 18 & 19 \\
\hline Digitalis & 2 & 13 \\
\hline$\beta$ Blockers & 17 & 23 \\
\hline Long acting nitrates & 7 & 19 \\
\hline Angiotensin converting enzyme (ACE) inhibitors & 2 & 1 \\
\hline Calcium antagonists & 8 & 13 \\
\hline \multicolumn{3}{|l|}{ Medication in CCU: } \\
\hline Frusemide & 105 & 104 \\
\hline Digitalis & 10 & 13 \\
\hline$\beta$ Blockers & 100 & 100 \\
\hline Long-acting nitrates & 90 & 91 \\
\hline ACE inhibitors & 13 & 10 \\
\hline Calcium antagonists & 0 & 2 \\
\hline Potassium sparers & 87 & 92 \\
\hline Thrombolysis & 66 & 58 \\
\hline \multicolumn{3}{|l|}{ Medication at discharge: } \\
\hline Frusemide & 105 & 103 \\
\hline Digitalis & 7 & 9 \\
\hline Long-acting nitrates & 81 & 82 \\
\hline ACE inhibitors & 11 & 7 \\
\hline Potassium sparers & 86 & 91 \\
\hline Oral anticoagulants & 11 & 17 \\
\hline Aspirin & 89 & 76 \\
\hline \multicolumn{3}{|l|}{ Mean (SD) heart rate (beats/min): } \\
\hline Supine & $69 \cdot 3(10 \cdot 5)$ & $70 \cdot 8(11 \cdot 6)$ \\
\hline Standing & $78 \cdot 5(13 \cdot 1)$ & $79 \cdot 2(14 \cdot 6)$ \\
\hline \multicolumn{3}{|l|}{ Mean (SD) blood pressure ( $\mathrm{mm} \mathrm{Hg}$ ): } \\
\hline \multicolumn{3}{|l|}{ Supine: } \\
\hline Systolic & $119 \cdot 0(17 \cdot 2)$ & $121 \cdot 3(16 \cdot 0)$ \\
\hline Diastolic & $75 \cdot 5(8 \cdot 8)$ & $76 \cdot 2(8 \cdot 9)$ \\
\hline \multicolumn{3}{|l|}{ Standing: } \\
\hline Systolic & $115 \cdot 5(17 \cdot 4)$ & $115 \cdot 3(18 \cdot 6)$ \\
\hline Diastolic & $79 \cdot 4(10 \cdot 8)$ & $78.0(10 \cdot 7)$ \\
\hline Mean (SD) ventricular & & \\
\hline end diastolic diameter (mm) & $58 \cdot 3(8 \cdot 4)$ & $58 \cdot 1(7 \cdot 5)$ \\
\hline Mean (SD) wall motion score ${ }^{\star}$ & $1.2(0 \cdot 4)$ & $1 \cdot 2(0 \cdot 4)$ \\
\hline Mean (SD) radiographic heart size $(\mathrm{ml}) \dagger$ : & & \\
\hline Total & $1040(271)$ & $1032(212)$ \\
\hline Relative $\ddagger$ & $543(122)$ & $542(90)$ \\
\hline
\end{tabular}

*According to Berning, et al. ${ }^{1821}$ †According to Jonsell. ${ }^{19} \ddagger$ To body surface area. before discharge on days 3-5. Heart size (absolute and relative to body surface area) was determined according to the method of Jonsell. ${ }^{19}$ The degree of pulmonary congestion was judged.

Routine haematology and serum biochemistry tests were performed and compliance was checked by counting tablets at each return visit.

All laboratory analyses (exercise test, echocardiography, radiography) were done blind by independent physicians and technicians.

\section{STATISTICAL ANALYSES}

Analysis of covariance was used for exercise tolerance data. Adjusted means were obtained, which allowed for the effect of the baseline exercise tolerance and also the effect of heart size (large or small). The estimated jugular venous pressure and respiratory rate at rest were analysed by the same methods. Differences between adjusted means and $95 \%$ confidence intervals for the differences were estimated. A Mantel-Haenszel $\chi^{2}$ test was used to assess if the treatments differed in frequency of pulmonary rales, third heart sound, peripheral oedema, hepatomegaly, and hepatojugular reflex at follow up. A check for treatment by heart size interaction was performed using the Breslow-Day test. For quality of life questions $95 \%$ confidence intervals were estimated according to Gardner and Altman for the median changes from baseline, a within treatment comparison. (Statistics with confidence: confidence intervals and statistical guidelines. BMF 1989;299:690.) A between treatment comparison was made using the Wilcoxon rank sum test. A P value $<0.05$ was considered significant.

Adjustments of the $\mathrm{P}$ values were performed with respect to measurements at multiple time points by a non-Bonferroni method. Statistical testing was performed at months 3 , 6 , and 12 and at the last known value. The last known value was obtained to overcome the potential bias of patients withdrawing at different times from the two treatment groups. If a patient withdrew from tests between visits at three and six months the assessment value at three months was entered at six and 12 months as the last known value. All patients with assessments at any follow up visits were entered in the analysis whether or not they were still taking the allocated treatment (intention to treat analysis). Data are presented as means (SD), or as medians when appropriate.

\section{Results}

CHARACTERISTICS AT BASELINE

Two hundred and ten patients entered the study (table 2). Their median age was 67 years and 173 were men. Class I heart failure according to the New York Heart Association was present in six patients, class II heart failure in 143, and class III in 61. A third heart sound was noted in 109 and rales in 194 . Transmural infarction was diagnosed in 171 
Table 3 Reasons for exclusion from study, 1988-90

\begin{tabular}{lc}
\hline & $\begin{array}{c}\text { No of patients } \\
(n=312)\end{array}$ \\
\hline Echocardiography not possible & 27 \\
No heart failure & 106 \\
Severe heart failure & 6 \\
Unstable angina & 18 \\
Valvar heart disease & 5 \\
Pulmonary disease & 16 \\
Intermittent claudication & 12 \\
Neurological disease & 16 \\
Rheumatoid disease & 2 \\
Haematological or malignant disease & 10 \\
Psychiatric disease & 6 \\
Other diseases & 28 \\
Known intolerance to $\beta$ blockade & 16 \\
Other catchment area & 19 \\
Alcohol misuse & 4 \\
Other research project & 3 \\
Language difficulties/consent not given & 9 \\
Not classified & 9 \\
\hline
\end{tabular}

and anterior or lateral infarction in 110 . Previous infarction was present in 35 and a history of left ventricular heart failure in 30 . Thrombolytic treatment was given to 124 .

The two treatment groups were similar with respect to age, weight, sex, class of heart failure, medical history, infarct size and location, left ventricular end diastolic diameter, wall motion score, vital signs, and cardiovascular drugs taken during the stay in the coronary care unit and at discharge. Before admission to hospital 13 patients randomly allocated xamoterol had received digoxin compared with two patients randomly allocated metoprolol. This difference was not present in the coronary care unit or at discharge. $\beta$ Receptor antagonists were given to 200 patients before randomisation. Most patients received treatment with frusemide, amiloride, long acting nitrates, and aspirin on discharge. The mean frusemide dose was $71 \mathrm{mg}$ (range 20-200) in both treatment groups at discharge. Angiotensin converting enzyme inhibitors were given to 18 patients and digitalis to 16 at discharge.

PATIENT ELIGIBILITY

A complete log book was kept during the first two years of inclusion ${ }^{20} ; 632$ patients surviving

Table 4 Reasons for withdrawal from study

\begin{tabular}{lll}
\hline & $\begin{array}{l}\text { Metroprolol } \\
(n=18)\end{array}$ & $\begin{array}{l}\text { Xamoterol } \\
(n=22)\end{array}$ \\
\hline Death & 5 & 6 \\
Deterioration in condition & 8 & 6 \\
Atrial fibrillation & 1 & 1 \\
Ventricular tachycardia & 0 & 3 \\
Possible adverse reaction & 2 & 2 \\
Patient defaulted & 0 & 1 \\
Study closed down & 2 & 1 \\
Other & 0 & 2 \\
\hline
\end{tabular}

Table 5 Adverse reactions reported in $\geqslant 5 \%$ of all patients

\begin{tabular}{llc}
\hline & $\begin{array}{l}\text { Metroprolol } \\
(n=77)\end{array}$ & $\begin{array}{l}\text { Xamoterol } \\
(n=44)\end{array}$ \\
\hline Vertigo & 19 & 9 \\
Cold extremities & 15 & 8 \\
Flatulence & 9 & 10 \\
Myocardial infarction & 7 & 6 \\
Angina pectoris & 8 & 4 \\
Impotence & 6 & 4 \\
Disturbed sleep & 7 & 2 \\
Diarrhoea & 6 & 1 \\
\hline
\end{tabular}

3-5 days after a myocardial infarction were registered. Two hundred and fifteen patients were not entered because they were older than 75. An amendment to the protocol was made after two years to include patients older than 75 in the study. Of the remaining 417 patients, 105 patients were entered in the study. One hundred and six patients were excluded because of lack of heart failure signs in the coronary care unit and six patients were excluded because of severe heart failure. Of the 312 excluded patients (table 3), 256 received $\beta$ blockade at the time of screening. Sixteen patients over 75 were entered during the remaining two years of inclusion.

CONCURRENT DRUG TREATMENTS

During follow up the median number of other drugs was 4 in both groups on all visits, except on the 12 month visit, when three other drugs were taken. At three months the dose of frusemide was increased in 10 patients taking metoprolol and in three taking xamoterol $(\mathrm{P}<$ $0.05)$. Mean doses of frusemide were not different between the two trial groups after three, six, and 12 months of follow up. At 12 months frusemide had been withdrawn in 17 patients taking metoprolol compared with 15 patients taking xamoterol. Angiotensin converting enzyme inhibitors were given to six patients taking metoprolol and nine taking xamoterol during follow up.

\section{TRIAL TREATMENTS}

Mean daily dose from baseline to three months was 135 (55) mg for metoprolol and 347 (92) $\mathrm{mg}$ for xamoterol. From three to six months the mean dose was 123 (63) $\mathrm{mg}$ for metoprolol and 324 (119) $\mathrm{mg}$ for xamoterol. From six to 12 months the dose was 116 (66) $\mathrm{mg}$ and 294 (145) $\mathrm{mg}$, respectively. Median dose was $100 \mathrm{mg}$ for metoprolol and $400 \mathrm{mg}$ for xamoterol on all visits. The trial dose was reduced because of symptoms of heart failure in 14 patients taking metoprolol and in 10 taking xamoterol $(\mathrm{P}=0.41)$.

\section{ECHOCARDIOGRAPHY AND LEFT VENTRICULAR} FUNCTION

The left ventricle was enlarged (left ventricular end diastolic diameter $\geqslant 28 \mathrm{~mm} / \mathrm{m}^{2}$ body surface area) in 143 patients. A mean wall motion score of $1.2(0.4)$ was found at baseline in 189 patients, corresponding to a mean ejection fraction ${ }^{21}$ of $36 \%$, which was similar in both treatment groups (table 2). The mean wall motion score was $1.0(0.4)$ in patients with enlarged left ventricles, corresponding to a mean baseline ejection fraction of $30 \%$. The mean wall motion score was significantly better in patients with normal left ventricular size $(1.4(0.3) v 1.0(0.4), \mathrm{P}<0.001)$.

\section{WITHDRAWALS}

Forty patients were withdrawn from randomised treatment during the one year follow up (table 4). Five patients receiving metoprolol and six receiving xamoterol died; three of the deaths in the metoprolol group occurred within eight days of entry. Disease deteriora- 
Table 6 Exercise variables. Values are means (SD)

\begin{tabular}{|c|c|c|}
\hline & Metoprolol & Xamoterol \\
\hline \multicolumn{3}{|c|}{ Exercise time (s): } \\
\hline Baseline & $391 \cdot 0(161 \cdot 8)$ & $386 \cdot 7(138 \cdot 7)$ \\
\hline 3 Months & $482.4(207.9)$ & $494.3(189.9)$ \\
\hline 12 Months & $508 \cdot 3(209 \cdot 3)$ & $528.0(198.6)$ \\
\hline \multicolumn{3}{|c|}{ Peak workload (W): } \\
\hline Baseline & $94.9(26.9)$ & $94 \cdot 3(23 \cdot 1)$ \\
\hline 3 Months & $110 \cdot 1(34 \cdot 7)$ & $112 \cdot 1(31 \cdot 6)$ \\
\hline 12 Months & $114.3(35.0)$ & $117 \cdot 7(33 \cdot 2)$ \\
\hline \multicolumn{3}{|c|}{ Heart rate at rest supine (beats/min): } \\
\hline Baseline & $69 \cdot 3(10 \cdot 5)$ & $70 \cdot 8(11 \cdot 6)$ \\
\hline 3 Months & $57.5(8.0)$ & $70 \cdot 3(9 \cdot 7)$ \\
\hline 12 Months & $59 \cdot 1(9 \cdot 1)$ & $71 \cdot 2(9 \cdot 3)$ \\
\hline \multicolumn{3}{|c|}{ Systolic blood pressure at rest supine $(\mathrm{mm} \mathrm{Hg})$ : } \\
\hline Baseline & $119 \cdot 0(17 \cdot 2)$ & $121 \cdot 3(16 \cdot 0)$ \\
\hline 3 Months & $125 \cdot 8(17 \cdot 0)$ & $134 \cdot 2(17 \cdot 7)$ \\
\hline 12 Months & $131 \cdot 6(17 \cdot 1)$ & $136 \cdot 1(17 \cdot 4)$ \\
\hline \multicolumn{3}{|c|}{ Heart rate at peak exercise (beats/minute): } \\
\hline Baseline & $113 \cdot 6(15 \cdot 7)$ & $115.9(20 \cdot 6)$ \\
\hline 3 Months & $110 \cdot 1(17 \cdot 4)$ & $119 \cdot 4(18 \cdot 2)$ \\
\hline 12 Months & $113.0(17 \cdot 2)$ & $124 \cdot 4(17 \cdot 9)$ \\
\hline \multicolumn{3}{|c|}{ Systolic blood pressure at peak exercise $(\mathrm{mm} \mathrm{Hg})$ : } \\
\hline Baseline & $158 \cdot 5(28 \cdot 5)$ & $156.9(28.8)$ \\
\hline 3 Months & $159.7(29 \cdot 4)$ & $163 \cdot 1(24 \cdot 3)$ \\
\hline 12 Months & $167 \cdot 8(27 \cdot 8)$ & $170.7(21.4)$ \\
\hline \multicolumn{3}{|c|}{ Peak respiratory rate (breaths/minute): } \\
\hline Baseline & $29 \cdot 4(5 \cdot 7)$ & $29 \cdot 2(5 \cdot 3)$ \\
\hline 3 Months & $31.0(5 \cdot 6)$ & $30.6(5.6)$ \\
\hline 12 Months & $32.6(5.8)$ & $31.6(5.8)$ \\
\hline \multicolumn{3}{|c|}{ Maximum ST depression at peak exercise $(\mathrm{mm})$ : } \\
\hline Baseline & $0.67(0.96)$ & $0.85(1.01)$ \\
\hline 3 Months & $0.61(0.84)$ & $0.70(0.93)$ \\
\hline 12 Months & $0.59(0.79)$ & $0.64(0.89)$ \\
\hline \multicolumn{3}{|c|}{ Blood lactate $(\mathrm{mmol} / \mathrm{l})$ : } \\
\hline Baseline & $4 \cdot 8(1 \cdot 5)$ & $4.9(1 \cdot 6)$ \\
\hline 3 Months & $6.0(1.9)$ & $6 \cdot 3(2 \cdot 1)$ \\
\hline 12 Months & $6.4(2.4)$ & $7.0(2.0)$ \\
\hline \multicolumn{3}{|c|}{ Peak Borg dyspnoea: } \\
\hline Baseline & $5 \cdot 1(2 \cdot 0)$ & $5 \cdot 0(2 \cdot 0)$ \\
\hline 3 Months & $6 \cdot 0(2 \cdot 2)$ & $5.7(2.0)$ \\
\hline 12 Months & $6 \cdot 4(2 \cdot 1)$ & $5.6(1.9)$ \\
\hline \multicolumn{3}{|c|}{ Peak Borg leg fatigue: } \\
\hline Baseline & $5 \cdot 6(2 \cdot 2)$ & $5 \cdot 5(2 \cdot 1)$ \\
\hline 3 Months & $6 \cdot 7(2 \cdot 1)$ & $6.6(2.0)$ \\
\hline 12 Months & $7 \cdot 4(1.9)$ & $6 \cdot 8(1 \cdot 7)$ \\
\hline \multicolumn{3}{|c|}{ Peak Borg chest pain: } \\
\hline Baseline & $0.4(1.0)$ & $0.7(1.5)$ \\
\hline 3 Months & $0 \cdot 7(1 \cdot 7)$ & $0.8(1.6)$ \\
\hline 12 Months & $0.5(1.4)$ & $0.6(1.5)$ \\
\hline
\end{tabular}

tion was the cause for withdrawal in 14 patients, eight taking metoprolol and six xamoterol. Five patients taking metoprolol and four xamoterol were withdrawn from the study because of worsening heart failure. Eight of these nine patients had enlarged left ventricular end diastolic diameter at baseline. Two patients taking metoprolol and three xamoterol were withdrawn because of unstable angina. All five had a normal left ventricular end diastolic diameter at baseline. Symptoms of heart failure improved in five patients after withdrawal. Eight patients who

Figure 1 Exercise tolerance in seconds at baseline and after three, six, and 12 months of follow up and at the last known value. The figure shows adjusted means and $95 \%$ confidence intervals for the difference in seconds between the treatment groups. were withdrawn showed improvement after revascularisation; two patients died four and 12 months after withdrawal. Seven of the 14 patients whose condition deteriorated were treated with open label $\beta$ blockade after withdrawal. Three patients taking xamoterol were withdrawn within one month because of ventricular tachycardia.

\section{EXERCISE TESTING}

Exercise tests were continued until either symptoms or criteria determining cardiac safety prevented continuation. Exercise tests were performed at three months in 201 patients, at six months in 193 patients, and at 12 months, the final visit, in 186 patients. The groups were comparable in baseline exercise tolerance, ST depression, blood lactate concentration after exercise, and ratings of symptoms on the Borg scale (table 6). Exercise time increased at three months compared with baseline values by $22 \%$ in the metoprolol group and $29 \%$ in the xamoterol group. There was no significant difference between the two groups at any of the follow up visits (figure 1). The mean increase in exercise time was largest at 12 months $(27 \%$ increase for metoprolol and $35 \%$ increase for xamoterol). The largest difference between the two treatment groups was $36 \mathrm{~s}$, or $6 \mathrm{~W}$ ( $9 \%$ of baseline exercise time and $6 \%$ of baseline exercise tolerance), at the last known value. The results were consistent in patients with normal and enlarged left ventricles.

Borg scale assessments showed fatigue to be the major limiting symptom at baseline and all follow up visits. Breathlessness and fatigue were the cause for stopping exercise in $>95 \%$, chest pain in $<17 \%$, arrhythmias $<5 \%$, and a fall in blood pressure in $<10 \%$ of all visits. The Borg scale ratings and blood lactate concentration increased on follow up $(P<$ 0.001 ), showing that some of the improvement in exercise tolerance could be explained by a higher degree of physical exertion. An analysis of the workload obtained at the maximal Borg scale rating of dyspnoea on entry compared with the workload obtained at the same Borg scale rating at 12 months showed an average $12 \%$ increase in exercise tolerance in both treatment groups $(P=0.002)$ on follow up.

Mean heart rate at rest $(P<0.001)$ and at peak exercise $(P<0.001)$, and mean systolic $(P<0.05)$ and diastolic $(P<0.05)$ blood pressures at rest were significantly higher in patients receiving xamoterol at all follow up visits. There was a mean decrease of heart rate of 9.9-11.4 beats/minute at rest and 3.6-0.8 beats/minute at peak exercise with metoprolol from baseline to follow up visits and a mean difference of $-0.5-0.7$ beats/minute at rest and a mean increase of $3.4-7.9$ beats/minute on exercise with xamoterol.

\section{QUALITY OF LIFE ASSESSMENT}

Improvements for both trial groups were seen in tiredness, chest pain, speed of walking, difficulty with daily tasks, speed of daily tasks (table 7). Breathlessness improved only with

$\begin{array}{lccccc}\text { Xamoterol } & 389 & 501 & 515 & 532 & 524 \\ \text { Metoprolol } & 395 & 481 & 494 & 502 & 488 \\ \text { 95\% Confidence } & \begin{array}{l}-17.1 \text { to } \\ \text { interval }\end{array} & \begin{array}{c}57.5 \\ \text { - }\end{array} & 59.8 \text { to } & -12.5 \text { to } & -4.2 \text { to } \\ \end{array}$

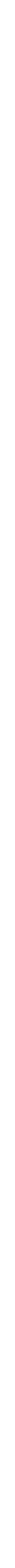


Table 7 Quality of life assessments during follow up

\begin{tabular}{|c|c|c|c|}
\hline & \multicolumn{2}{|c|}{$\begin{array}{l}\text { Change from baseline } \\
\text { (95\% confidence interval) }\end{array}$} & \multirow{2}{*}{$\begin{array}{l}P \text { value for } \\
\text { difference } \\
\text { between metoprolol } \\
\text { and xamoterol }\end{array}$} \\
\hline & Metoprolol & Xamoterol & \\
\hline \multicolumn{4}{|c|}{ Tiredness: } \\
\hline $0-3$ & -1 to -0.5 & -1 to -0.5 & 0.92 \\
\hline $0-6$ & -1 to -0.5 & -1 to -0.5 & $0 \cdot 28$ \\
\hline $0-12$ & -1 to -0.5 & -1 to -0.5 & 0.90 \\
\hline \multicolumn{4}{|c|}{ Breathlessness: } \\
\hline $0-3$ & 0 to 0 & -0.5 to 0 & 0.003 \\
\hline $0-6$ & 0 to 0 & -0.5 to 0 & 0.046 \\
\hline $0-12$ & -0.5 to 0 & -0.5 to 0 & 0.48 \\
\hline \multicolumn{4}{|c|}{ Chest pain: } \\
\hline $0-3$ & -1 to -0.5 & -0.5 to -0.5 & 0.53 \\
\hline $0-6$ & -1 to $-0 \cdot 5$ & -1 to -0.5 & 0.93 \\
\hline $0-12$ & -1 to -0.5 & -1 to -0.5 & 0.99 \\
\hline \multicolumn{4}{|c|}{ Palpitations: } \\
\hline $0-3$ & 0 to 0 & 0 to 0 & 0.99 \\
\hline $0-6$ & 0 to 0 & 0 to 0 & 0.38 \\
\hline $0-12$ & -0.5 to 0 & 0 to 0 & 0.44 \\
\hline \multicolumn{4}{|c|}{ Difficulty with walking: } \\
\hline $0-3$ & 0 to 0 & -0.5 to 0 & 0.39 \\
\hline $0-6$ & 0 to 0 & -0.5 to 0 & 0.49 \\
\hline $0-12$ & 0 to 0 & -0.5 to 0 & 0.41 \\
\hline \multicolumn{4}{|c|}{ Speed of walking: } \\
\hline $0-3$ & -1 to -0.5 & -0.5 to -0.5 & 0.92 \\
\hline $0-6$ & -0.5 to -0.5 & -1 to -0.5 & 1.00 \\
\hline $0-12$ & -1 to -0.5 & -1 to -0.5 & 0.99 \\
\hline \multicolumn{4}{|c|}{ Difficulty with daily tasks: } \\
\hline $0-3$ & -1 to -0.5 & -1 to -0.5 & 1.00 \\
\hline $0-6$ & -1 to -0.5 & -1 to -0.5 & 0.96 \\
\hline $0-12$ & -1 to -1 & -1 to -0.5 & 0.99 \\
\hline \multicolumn{4}{|c|}{ Confidence: } \\
\hline $0-3$ & -0.5 to 0 & -0.5 to 0 & 0.99 \\
\hline $0-6$ & -0.5 to 0 & -0.5 to 0 & 0.83 \\
\hline $0-12$ & -0.5 to 0 & -0.5 to 0 & 1.00 \\
\hline \multicolumn{4}{|c|}{ Quality of sleep: } \\
\hline $0-3$ & 0 to 0 & -0.5 to 0 & $0 \cdot 30$ \\
\hline $0-6$ & -0.5 to 0 & -0.5 to 0 & 0.96 \\
\hline $0-12$ & -0.5 to 0 & -0.5 to 0 & 0.94 \\
\hline
\end{tabular}

${ }^{\star}$ Answers were given on a 4 or 5 point scale. Minus signs mean improvements compared with baseline scores. $95 \%$ confidence intervals were calculated according to Gardner and Altman.

xamoterol on follow up (95\% confidence interval -0.5 to -0.5 at the last known value) and the improvement was better than that in the metoprolol group at three $(P=0.003)$ and six months $(P=0.046)$ but not at 12 months $(P=0 \cdot 48)$. There was no improvement in palpitations, difficulty with walking, mood,

Table 8 Clinical signs of heart failure at baseline and follow up. Values are numbers (percentages) of patients unless stated otherwise

\begin{tabular}{|c|c|c|c|}
\hline Sign & Metoprolol & Xamoterol & Pvalue \\
\hline \multicolumn{4}{|l|}{ Gallop rhythm: } \\
\hline Baseline & $33(31)$ & $43(41)$ & \\
\hline 3 Months & $14(14)$ & $12(12)$ & 0.63 \\
\hline 6 Months & $19(19)$ & $21(21)$ & 0.50 \\
\hline 12 Months & $17(18)$ & $16(17)$ & 0.82 \\
\hline \multicolumn{4}{|l|}{ Rales: } \\
\hline Baseline & $34(32)$ & $46(44)$ & \\
\hline 3 Months & $21(21)$ & $18(18)$ & 0.72 \\
\hline 6 Months & - & & \\
\hline 12 Months & $18(19)$ & $11(11)$ & $0 \cdot 15$ \\
\hline \multicolumn{4}{|c|}{ Mean (SD) respiratory rate at rest (beats/minute): } \\
\hline Baseline & $16.8(3.9)$ & $16.5(3.7)$ & \\
\hline 3 Months & $15.0(3.2)$ & $15 \cdot 1(3 \cdot 3)$ & 0.92 \\
\hline 6 Months & $15 \cdot 5(3 \cdot 1)$ & $15 \cdot 5(3.3)$ & $1 \cdot 00$ \\
\hline 12 Months & $15 \cdot 3(3.4)$ & $15 \cdot 3(3 \cdot 5)$ & 1.00 \\
\hline \multicolumn{4}{|c|}{ Mean (SD) jugular venous pressure $\left(\mathrm{cm} \mathrm{H}_{2} \mathrm{O}\right)$ : } \\
\hline Baseline & $9 \cdot 2(1 \cdot 6)$ & $9.5(1.5)$ & \\
\hline 3 Months & $9 \cdot 1(1 \cdot 3)$ & $8 \cdot 8(1.0)$ & $0 \cdot 13$ \\
\hline 6 Months & $9 \cdot 2(1 \cdot 3)$ & $8.8(1.0)$ & 0.09 \\
\hline 12 Months & $9 \cdot 0(1 \cdot 1)$ & $8 \cdot 8(1.0)$ & 0.90 \\
\hline \multicolumn{4}{|c|}{ Peripheral oedema: } \\
\hline Baseline & $7(7)$ & $6(6)$ & \\
\hline 3 Months & $11(11)$ & $4(4)$ & $0 \cdot 15$ \\
\hline 6 Months & $17(17)$ & $4(4)$ & 0.02 \\
\hline 12 Months & $13(14)$ & $6(6)$ & 0.27 \\
\hline \multicolumn{4}{|l|}{ Hepatomegaly: } \\
\hline Baseline & 0 & $1(1)$ & \\
\hline 3 Months & 0 & $1(1)$ & 0.62 \\
\hline 6 Months & $1(1)$ & $2(2)$ & 0.99 \\
\hline 12 Months & $1(1)$ & $1(1)$ & 0.85 \\
\hline \multicolumn{4}{|c|}{ Positive hepatojugular reflex: } \\
\hline Baseline & $30(31)$ & $34(34)$ & \\
\hline 3 Months & $26(27)$ & $17(17)$ & \\
\hline 6 Months & $27(28)$ & $19(20)$ & 0.67 \\
\hline 12 Months & $22(24)$ & $18(20)$ & 0.92 \\
\hline
\end{tabular}

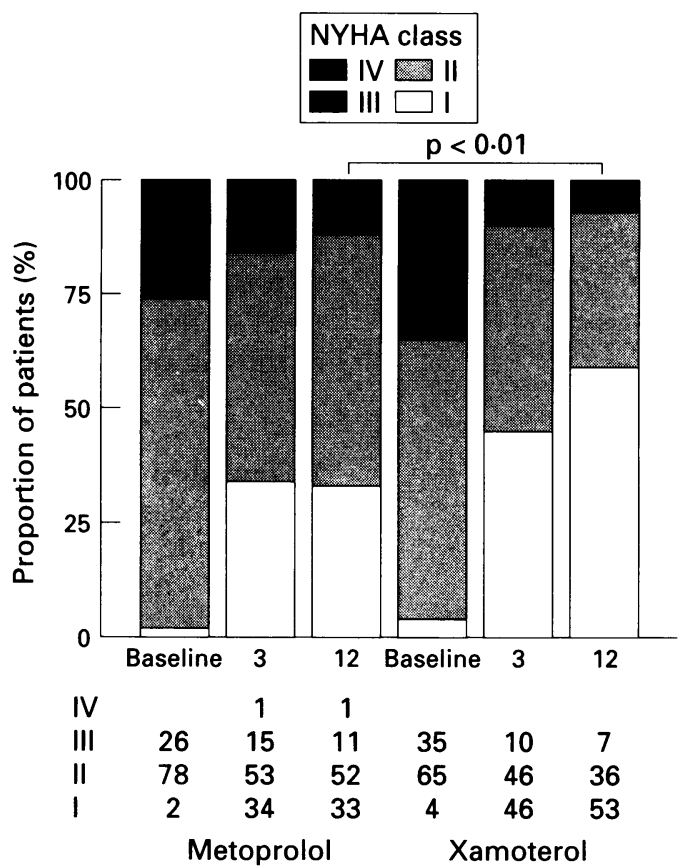

Figure 2 New York Heart Association (NYHA) functional class at baseline and after three and 12 months of follow up. Numbers of patients in each class are given below the histogram.

confidence, and quality of sleep. No other differences between the treatment groups were found.

\section{CLINICAL ASSESSMENT}

Clinical signs improved on follow up, but no differences were seen between the two treatment groups in frequency of rales, third heart sound, respiratory rate at rest, hepatomegaly, or hepatojugular reflex (table 8). Fewer patients taking xamoterol had peripheral oedema on follow up, which was significant at six months ( $4 \%$ and $17 \%$, respectively; $\mathrm{P}=$ $0 \cdot 02)$. Estimated jugular venous pressure was slightly lower with xamoterol; at six months the adjusted mean was $8.7 \mathrm{~cm} \mathrm{H}_{2} \mathrm{O}$ and $9 \cdot 1$ cm $\mathrm{H}_{2} \mathrm{O}$, respectively $(\mathrm{P}=0 \cdot 09)$. Patients' weight increased by $1.8 \mathrm{~kg}$ with metoprolol and declined by $0.8 \mathrm{~kg}$ with xamoterol. The mean New York Heart Association class of heart failure (figure 2) improved from $2 \cdot 2$ at entry to 1.8 at 12 months with metoprolol and from 2.3 to 1.5 with xamoterol $(P<0.01$, for difference between groups at 12 months). Heart failure deteriorated by one functional class in seven patients in the metoprolol group and four in the xamoterol group from baseline to 12 months; but heart failure did not deteriorate by more than one class in any patient.

ADVERSE EXPERIENCES AND ADMISSIONS TO HOSPITAL

Within 12 months of entry 72 patients taking xamoterol and 85 taking metoprolol $(\mathrm{P}<$ $0.07)$ reported 166 and 186 adverse reactions, respectively. Vertigo, cold extremities, flatulence, angina pectoris, impotence, myocardial infarction, disturbed sleep, and diarrhoea were each reported by at least $5 \%$ of all patients (table 5). More adverse reactions 
except for flatulence were reported by patients taking metoprolol. The reinfarction rate was low in both treatment groups: $7 \%$ (seven patients) with metoprolol and $6 \%$ (six patients) with xamoterol. There was no difference between the treatments in numbers of visits to hospital. The number of days spent in hospital was also similar in both groups $(5 \cdot 2$ $(9.4)$ in the metoprolol group and $6.5(12.0)$ in the xamoterol group) $(P=0.33)$.

\section{Discussion}

Controlled studies on exercise tolerance with $\beta$ blockade have mainly been performed in patients with chronic heart failure caused by idiopathic dilated cardiomyopathy. During the first month of treatment reduced exercise tolerance $^{22}$ or no improvement was seen. ${ }^{23}$ During long term treatment improvement was observed, ${ }^{10}{ }^{15}$ indicating that a short term deterioration may be expected before improvement is obtained. With xamoterol improvement has been reported after 1-3 months. ${ }^{122425}$ No improvement in exercise tolerance was found with xamoterol in patients with severe heart failure. ${ }^{14} \beta$ Receptor antagonists with vasodilatory effects such as labetalol, ${ }^{26}$ bucindolol, ${ }^{27}$ and carvedilol ${ }^{28}$ also improve exercise tolerance, but there are no controlled comparisons between different types of $\beta$ blockade and no trials have been reported in patients with heart failure after myocardial infarction.

Exercise tolerance improved both with metoprolol and xamoterol in our study, with no significant differences between the treatment groups. The improvement with xamoterol over one year was similar to that seen in the German austrian xamoterol study, ${ }^{12}$ a similar workload at a similar peak exercise heart rate being achieved. The $27 \%$ improvement over one year with metoprolol is greater than the $16 \%$ improvement seen with digitalis in the German study but $8-9 \%$ less than the effect of xamoterol. The improvement from baseline must be interpreted with caution as we did not use a placebo group. In a previous study with exercise testing after mainly uncomplicated myocardial infarction a similar improvement was found with both metoprolol and placebo, indicating the natural course of exercise tolerance during the year after infarction. ${ }^{29}$ Another reason for caution when interpreting the data is that the higher exercise time during follow up is achieved at a higher degree of physical exertion according to the Borg scale data, measurements of lactate concentration, and respiratory rate. The additional analysis of Borg scale data supports a true $12 \%$ improvement in both treatment groups at 12 months, as previously noted. The improvement in exercise tolerance was similar in the subgroups of patients with normal and enlarged left ventricles, which means that exercise time improves also in patients with a more obvious depression of left ventricular systolic function. We found significant differences in heart rate and blood pressure between the trial drugs at rest and on exercise, which shows the partial agonist effect of xamoterol. One reason for the lack of additional effect on exercise tolerance with xamoterol could be a higher oxygen demand shown by Thierfelder et al with xamoterol ${ }^{30}$ but disputed by Rousseau et al. ${ }^{31}$

One clinical benefit of xamoterol is reflected in fewer patients with peripheral oedema, and this might be related to the difference in weight between treatment groups during follow up. Increased doses of frusemide were also more frequent in the metoprolol group at three months, although mean doses were similar in both treatment groups during follow up. Metoprolol causes patients with heart disease to gain weight. ${ }^{32}$ It may affect lipolysis. ${ }^{33}$ No other significant differences on clinical assessments could be detected, indicating similar effects of the drugs.

Quality of life questionnaires indicate an improvement with time in both treatment groups. This finding must, however, be interpreted with caution because of the lack of a control group. Only breathlessness was significantly better in patients taking xamoterol during the first six months, indicating some clinical benefit and in agreement with other studies. ${ }^{12}$ Fluid retention in patients taking metoprolol might be one reason why breathlessness did not improve with metoprolol. We previously found that ventilation increases in patients with heart failure treated with $\beta_{1}$ receptor antagonists devoid of agonist activity without reducing exercise tolerance, peak oxygen uptake, and anaerobic threshold. ${ }^{34}$ The beneficial effects of xamoterol on oedema and breathlessness may explain the difference in New York Heart Association functional class at 12 months.

Safety data show a low mortality and morbidity for xamoterol and metoprolol in comparison with mortality in patients with a comparable wall motion score ${ }^{3}$ or similar clinical inclusion criteria. ${ }^{7}$ The low mortality in our study suggests a superior effect of $\beta$ receptor antagonists in secondary prevention after myocardial infarction in high risk patients. ${ }^{35}$ Our figures are in agreement with one study with a partial agonist, acebutolol, in high risk patients ${ }^{36}$ but in conflict with other studies showing that prognosis is improved more with $\beta$ receptor antagonists without partial agonist activity. ${ }^{11}$ However, our study was not designed to look at effects on mortality and the data must therefore be interpreted with caution. The reduction in mortality after myocardial infarction with metoprolol is seen with a dose of $200 \mathrm{mg}^{37}$ and the lower doses used in heart failure may be less effective for purposes of affecting mortality. The Metoprolol in Dilated Cardiomyopathy study, however, showed that there was some benefit on the combined end point of mortality and morbidity in patients with dilated cardiomyopathy with metoprolol at a dose comparable with our mean dose. ${ }^{10}$ The safety of xamoterol shown in our study in mild to moderate heart failure is in contrast to the findings in the xamoterol in severe heart failure study, in 
which mortality was increased. ${ }^{14}$

We have thus shown that $\beta$ receptor antagonists with and without partial agonist activity are well tolerated by patients with mild to moderate heart failure after a myocardial infarction, as has previously been shown for patients with uncomplicated infarctions. ${ }^{29}$ The frequency of adverse reactions and the withdrawal rate were no higher in our study than in other heart failure studies with angiotensin converting enzyme inhibitors, ${ }^{5-7}$ and only $5 \%$ of our patients showed a deterioration. The fear of deterioration in heart failure is in most cases not warranted, although we used a fast titration protocol and standard doses of metoprolol and xamoterol. A similar incidence of heart failure was found in patients allocated to $\beta$ blockade compared to placebo in a pooling off all long term secondary prevention studies with $\beta$ blockade after myocardial infarction. ${ }^{38} \mathrm{~A}$ beneficial treatment effect of $\beta$ blockade in selected patients with clinical evidence of heart failure is possible because there may be a different outcome in these patients compared with patients with uncomplicated myocardial infarction, as shown by the differentiated haemodynamic response in the Metoprolol in Acute Myocardial Infarction trial. ${ }^{39}$ The Betablocker Heart Attack Trial showed an increase in incidence of heart failure confined to patients with normal ejection fraction and not in patients with reduced ejection fraction. ${ }^{40}$

Nearly all our patients were treated with open $\beta$ blockade as part of our routine treatment of myocardial infarction before inclusion in the study. We therefore knew that most patients tolerated at least low doses of $\beta$ blockade, a strategy used in studies with angiotensin converting enzyme inhibitors. ${ }^{6}$ Most patients (82\%) with exclusion criteria according to the study protocol obviously tolerated $\beta$ blockade. Only 16 patients were excluded because they could not tolerate such blockade.

The mechanism behind the improvement after treatment with $\beta$ blockade in patients with heart failure is unclear. The lack of additional effect with xamoterol on exercise tolerance in spite of its beneficial haemodynamic properties indicates that the $\beta_{1}$ receptor blocking effect is the most important. $\beta$ Receptor antagonists with and without selectivity, partial agonist activity, and vasolidatory effects improve exercise tolerance..$^{1524-29}$ Suggested mechanisms include protection against $\beta$ receptor downregulation, ${ }^{41}$ anti-ischemic effects, ${ }^{42}$ restoration of the chronotropicinotropic relation, ${ }^{43}$ protection against catecholamine toxicity, ${ }^{44}$ and inhibition of neurohormonal stimulation of the reninangiotensin system. ${ }^{23}$ Our study does not allow us to draw any conclusion about these beneficial mechanisms, but they are probably all more obviously affected by a $\beta$ receptor antagonist devoid of partial agonist activity. $\beta$ Receptor antagonists with vasodilatory properties may prove to be superior to metoprolol or xamoterol. Further comparative studies are needed to answer this question.
We conclude that both metoprolol and xamoterol can be used safely in patients with mild to moderate heart failure after myocardial infarction, with improvement of exercise tolerance, quality of life, and clinical assessment in the two treatment groups and only minor differences in functional outcome during one year of follow up. The use of xamoterol in patients with acute myocardial infarction may be disputable until a proper mortality study is performed because of the adverse data on mortality in severe chronic heart failure. ${ }^{14}$

We thank Zeneca Pharmaceuticals, Alderley Park, for financial help, and Kjell Pennert at Zeneca AB, Gothenburg, for statistical support. The study was also supported by grants from the Swedish National Heart and Lung Foundation, the Swedish Society of Medicine, and the Karolinska Institute Foundation. We also thank E Johansson, M-L O'Konor, and E LinderWe also thank E Johansson, M-L O'Konor, and E Linder-
Klingsell for invaluable help; SV Eriksson for cross sectional echocardiographic evaluations; and A Boavida, R Ude'n, and echocardiographic evaluations; and $A$
$T$ Ösby for chest $x$ ray evaluations.

1 Wolk MJ, Scheidt S, Killip T. Heart failure complicating acute myocardial infarction. Circulation 1972;45: 1125-38.

2 Dwyer EM, Greenberg HM, Steinberg G, Multicenter Postinfarction Research Group. Clinical characteristics and natural history of pulmonary congestion during acute myocardial infarction. Am $₹$ Cardiol 1989;63: 1423-8.

3 Berning J, Steensgaard-Hansen F, Appleyard M. Relative prognostic value of clinical heart failure and early echocardiographic parameters in acute myocardial infarction. Cardiology 1991;79:64-72.

4 Captopril-Digoxin Multicenter Research Group. Comparative effects of therapy with captopril and digoxin in patients with mild to moderate heart failure. FAMA 1988;259:539-44.

5 SOLVD Investigators. Effect of enalapril on survival in patients with reduced left ventricular ejection fractions and congestive heart failure. $N$ Engl $\mathcal{F}$ Med 1991;325: 293-302.

6 Pfeffer MA, Braunwald E, Moye' LA, Rutherford J, Bosta L, Brown EJ, et al. Effects of captopril on mortality and morbidity in patients with left ventricular dysfunction morbidity in patients with left ventricular dysfunction after myocardial infarction. Results of the Survival and Ventricular

7 Acute Infarction Ramipril Efficacy (AIRE) Study Investigators. Effect of ramipril on mortality and morbidity of survivors of acute myocardial infarction with clinical evidence of heart failure. Lancet 1993;342:821-8.

8 Olsson G, Rehnqvist N. Effect of metoprolol in postinfarction patients with increased heart size. Eur Heart $\mathcal{f}$ 1986;7:468-74.

9 Chadda K, Goldstein S, Byington R, Curb JD. Effect of propranolol after acute myocardial infarction in patients with congestive heart failure. Circulation 1986;73: with cong-10.

10 Waagstein F, Bristow MR, Swedberg K, Camerini F, Fowler MB, Silver MA, et al. Beneficial effects of metoprolol in idiopathic dilated cardiomyopathy. Lancet 1993;342:1441-6.

11 Kjekshus JK. Importance of heart rate in determining beta-blocker efficacy in acute and long-term acute myocardial infarction trials. Am $f$ Cardiol 1986;57: 43-7F.

12 German and Austrian Xamoterol Study Group. Doubleblind placebo controlled comparison of digoxin and xamoterol in chronic heart failure. Lancet 1988; xamoterol

13 Marlow HF, Lewis JA. Effects of xamoterol on mortality in mild to moderate heart failure [abstract]. Eur Heart $\mathcal{f}$ 1990;11:132.

14 Xamoterol In Severe Heart Failure Study Group. Xamoterol in severe heart failure. Lancet 1990;336:1-6.

15 Engelmeier RS, O'Conell, JB, Walsh R, Rad N, Scanlon $\mathrm{PF}$, Gunnar RM. Improvement in symptoms and exercise tolerance by metoprolol in patients with dilated cise tolerance by metoprolol in patents with dilated controlled trial. Circulation 1985;72:536-46.

16 Gardin JM, Henry WL, Savage DD, Ware JH, Burn C, Borer JS. Echocardiographic measurements in normal subjects: evaluation of an adult population without clinisubjects: evaluation of an adult population without clini-
cally apparent heart disease. $\mathcal{F}$ Clin Ultrasound 1979;7: cally appar $439-47$.

17 Borg GAV. Psychophysical bases of perceived exertion. Med Sci Sports Exerc 1982;14:377-81.

18 Berning J, Steensgaard-Hansen F. Early estimation of risk by echocardiographic determination of wall motion index in an unselected population with acute myocardial infarction. Am $\mathcal{F}$ Cardiol 1990;65:567-76.

19 Jonsell S. A method for determination of the heart size by teleroentgenographs (a heart volume index). Acta Radiol 
$1939 \cdot 20 \cdot 325-40$

20 Persson H, Linder-Klingsell E, Eriksson SV, Erhardt L. Heart failure after myocardial infarction: the importance of diastolic dysfunction. A clinical and echocardiographic study. Eur Heart f 1995;16:496-505.

21 Berning J, Rokkedal Nielsen J, Launbjerg J, Fogh J, Mickley H, Andersen PE. Rapid estimation of left ventricular ejection fraction in acute myocardial infarction by echocardiographic wall motion analysis. Cardiology 1992;80:257-66.

22 Ikram H, Fitzpatrick D. Double-blind trial of chronic oral beta blockade in congestive cardiomyopathy. Lancet 1981;ii:490-3.

23 Currie PF, Kelly MJ, McKenzie A, Harper RW, Lim YL, Federman J, et al. Oral beta-adrenergic blockade with metoprolol in chronic severe dilated cardiomyopathy. $f$ Am Coll Cardiol 1984;3:203-9.

24 Vigholt-Sörensen E, Faergeman O, Snow HM. Effects of xamoterol, a $\beta_{1}$ adrenoceptor partial agonist, in patients with ischaemic dysfunction of the left ventricle. Br Heart f 1989;62:335-41.

25 Waller DG, Webster J, Sykes CA, Bhalla KK, Wray R. Clinical efficacy of xamoterol, a beta - -adrenoceptor partial agonist, in mild to moderate heart failure. Eur Heart $\mathcal{f}$ tial agonist, in mild

26 Leung WH, Lau C-P, Wong C-K, Cheng CH, Tai YT, Lim SP. Improvement in exercise performance and hemodynamics by labetalol in patients with idiopathic dilated cardiomyopathy. Am Heart f 1990;119:884-90.

27 Pollock SG, Lystash JC, Tedesco C, Craddock G, Smucker ML. Usefulness of bucindolol in congestive heart failure. Am F Cardiol 1990;66:603-7.

28 Krum H, Schwartz B, Sackner-Bernstein J, Penn J, Goldsmith RL, Kukin ML, et al. Double-blind, placeboGolds ited RL Kun in controlled study of the long-term efficacy of carvedilol in
patients with severe heart failure treated with convertingpatients with severe heart failure treated with converting
enzyme inhibitors. $7 \mathrm{Am}$ Coll Cardiol 1993;21:114A.

29 Olsson G, Rehnqvist N, Lundman T, Melcher A. Metoprolol treatment after acute myocardial infarction. Effects on ventricular arrhythmias and exercise tests during 6 months. Acta Med Scand 1981;210:59-65.

30 Thierfelder L, Holubarsch C, Hasenfuss G, Heiss HW, Just $H$. The effect of the partial beta-1-adrenoceptor agonist xamoterol on hemodynamics and myocardial energetics in patients with dilated cardiomyopathy. fCardiovasc Pharmacol 1991;17:593-9.

31 Rousseau MF, Pouleur H, Vincent MF. Effects of cardioselective $\beta_{1}$-partial agonist ('Corwin') on left ventricular function and metabolism in patients with previous myocardial infarction. Am $\mathcal{f}$ Cardiol 1983;51:1267-74.

32 Rössner S, Taylor C, Byington R, Furberg C. Weight gain after therapy with beta-blockade. Swedish Society of
Medicine. Hygiea 1989;98:189.

33 Meiler SE, Leier CV. Effects of beta-adrenergic stimulation on skeletal-muscle conditioning. Heart Failure 1986; 128-37.

34 Persson H, Erhardt L, Melcher A, Nygren A. Aerobic responses in exercise testing without and with betablocking therapy in patients with chronic heart failure [abstract]. Symposium on exercise testing in congestive heart failure, European Society of Cardiology, Brussels, 1990.

35 Beta-Blocker Pooling Project Research Group. The betablocker pooling project (BBPP): subgroup findings from randomized trials in post infarction patients. Eur Heart $\mathcal{F}$ randomized triak.

36 Boissel J-P, Leizorovicz A, Picolet H, Peyrieux J-C, for the APSI Investigators. Secondary prevention after high-risk acute myocardial infarction with low-dose acebutolol. Am f Cardiol 1990;66:251-60.

37 Hjalmarsson $\AA$, Elmfeldt D, Herlitz J, Holmberg S, Malek I, Nyberg G, et al. Effect on mortality of metoprolol in acute myocardial infarction: a double-blind randomised trial. Lancet $1981 ; \mathbf{i i}: 823-6$.

38 Yusuf $S$, Peto $R$, Lewis J, Collins $R$, Sleight P. Betablockade during and after myocardial infarction: an blockade during and after myocardial infarction: an overview of the
$1985 ; 26: 335-71$

39 Held P, Corbeij HMA, Dunselman P, Hjalmarsson Å, Murray D, Swedberg K, for the Haemodynamic Study Group of the MIAMI trial. Hemodynamic effects of metoprolol in acute myocardial infarction. A randomized, placebo-controlled multicenter study. Am $\mathcal{f}$ Cardiol 1985;56:47-54G.

40 Jafri SM, Khaja F, McFarland T, Capone R, Dahdah S, Haywood J, et al. Efficacy of propranolol therapy after acute myocardial infarction related to coronary arterial anatomy and left ventricular function. $\mathrm{Am} f \mathrm{Cardiol}$ anatomy and left

41 Fowler MB, Bristow MR, Laser JA, Ginsburg R, Scott LB, Schroeder JS. Beta blocker therapy in severe heart failure: improvement related to beta -adrenergic $_{1}$ receptor up regulation? [Abstract.] Circulation 1984;70: II-112.

42 Boström PÅ, Balldin M, Lilja B, Johansson B. The effect of atenolol on the left ventricular performance in patients with angina pectoris measured with isotope technique. Acta Med Scand 1988;223:239-45.

43 Mulieri LA, Hasenfuss G, Leavitt B, Allen PD, Alpert NR. Altered myocardial force-frequency relation in human Altered myocardial force-frequency relatio
heart failure. Circulation 1992;85:1743-50.

44 Shanes JG, Subramanian R, Thompson EB, O'Neill HK, Kondos GT, Shanks P, et al. Chronic beta blockade in the myopathic Syrian hamster [abstract]. Clin Res 1985; 33:818. 